\title{
Global patterns of change in discharge regimes for 2100
}

\author{
F. C. Sperna Weiland ${ }^{1,2}$, L. P. H. van Beek ${ }^{1}$, J. C. J. Kwadijk ${ }^{2}$, and M. F. P. Bierkens ${ }^{1,3}$ \\ ${ }^{1}$ Department of Physical Geography, Utrecht University, P.O. Box 80115, 3508 TC Utrecht, The Netherlands \\ ${ }^{2}$ Deltares, P.O. Box 177, 2600 MH Delft, The Netherlands \\ ${ }^{3}$ Deltares, P.O. Box 80015, 3508 TA Utrecht, The Netherlands
}

Correspondence to: F. C. Sperna Weiland (frederiek.sperna@ deltares.nl)

Received: 9 November 2011 - Published in Hydrol. Earth Syst. Sci. Discuss.: 13 December 2011

Revised: 3 March 2012 - Accepted: 22 March 2012 - Published: 2 April 2012

\begin{abstract}
This study makes a thorough global assessment of the effects of climate change on hydrological regimes and their accompanying uncertainties. Meteorological data from twelve GCMs (SRES scenarios A1B and control experiment 20C3M) are used to drive the global hydrological model PCR-GLOBWB. This reveals in which regions of the world changes in hydrology can be detected that have a high likelihood and are consistent amongst the ensemble of GCMs. New compared to existing studies is: (1) the comparison of spatial patterns of regime changes and (2) the quantification of notable consistent changes calculated relative to the GCM specific natural variability. The resulting consistency maps indicate in which regions the likelihood of hydrological change is large.

Projections of different GCMs diverge widely. This underscores the need of using a multi-model ensemble. Despite discrepancies amongst models, consistent results are revealed: by 2100 the GCMs project consistent decreases in discharge for southern Europe, southern Australia, parts of Africa and southwestern South-America. Discharge decreases strongly for most African rivers, the Murray and the Danube while discharge of monsoon influenced rivers slightly increases. In the Arctic regions river discharge increases and a phase-shift towards earlier peaks is observed. Results are comparable to previous global studies, with a few exceptions. Globally we calculated an ensemble mean discharge increase of more than ten percent. This increase contradicts previously estimated decreases, which is amongst others caused by the use of smaller GCM ensembles and different reference periods.
\end{abstract}

\section{Introduction}

Climate change will have notable effects on global runoff regimes and will affect water availability for agriculture and ecosystems as well (Arnell, 2003; Liu et al., 2008, 2009; Oki and Kanae, 2006; Vörösmarty et al., 2000). To anticipate for these changes, reliable assessments of the hydrological effects of climate change, including information on uncertainties are needed (Murphy et al., 2004; Giorgi and Mearns, 2002; IPCC, 2007). Studies investigating hydrological effects of climate change on continental or global scale are often based on results from General Circulation Models (GCMs). However, especially for precipitation, GCMs produce quite varying and even contradictory results (Covey et al., 2003; Meehl et al., 2000).

There have been quite a number of studies focusing on the hydrological consequences of climate change on a global scale. Multiple studies investigated future changes in global precipitation (for an overview see IPCC, 2007; Murphy et al., 2004; Giorgi and Mearns, 2002; Meehl et al., 2000). In this study we focus on changes in global discharge, hereby providing additional information on local water availability and changes in river hydrology as changes in river runoff and water availability are also influenced by evaporation (Kingston et al., 2009; Oudin et al., 2005), particularly in the drier regions (Africa and parts of Australia) and by snow accumulation and melt influencing the timing of the annual runoff cycle in northern regions/higher elevation zones (Immerzeel et al., 2010; Viviroli et al., 2011). Therefore, for a proper assessment of changes in volume and timing of river discharge, runoff accumulation and runoff routing (Sperna Weiland et 
al., 2011) is required. Such extensive assessments will in the end provide important information on local water availability, conditions for navigation, ecosystems and hydropower generation.

Table A, provided as Supplement, provides an overview of previous hydrological impact assessments which are discussed in this study. All these studies focus on change in runoff or discharge, Table A (in the Supplement) lists the differences in various aspects. This comparison provides some background information for this current study and enables us to evaluate the value of the different techniques used in hydrological impact assessments.

Overall the results of these studies project a decrease in runoff for southern Europe, north and south Africa, southwestern USA, Mexico and Brazil and an increase in discharge for Monsoon driven and Arctic rivers. Several studies (Alcamo and Henrichs, 2002; Arnell, 1999, 2003; Nijssen et al., 2001; Vörösmarty et al., 2000) used a change factor method instead of directly applying the climate model data for the future period. Within the change factor method observed precipitation, temperature or runoff fields are adjusted with a change factor derived from climate model data and those adjusted time-series are then used to derive future runoff and discharge changes. The method assumes that change is more reliable than absolute values. However, this only holds under the assumption of a constant model bias through time. Furthermore change in variability is ignored (Fowler et al., 2007). Although computationally more demanding than the change factor method, directly forcing a hydrological model with climate model data for current and future climate and calculation of differences in obtained discharges may give more reliable estimates of changes in variability and extremes.

Change in runoff can also directly be derived from runoff fields calculated by GCMs (Sperna Weiland et al., 2011). Unfortunately such data is not accessible for most models and in most GCMs river routing is not included. To obtain information on changes in river regimes, additional routing of GCM runoff fields is needed (Arora and Boer, 2001; Milly et al., 2005; Nohara et al., 2006). To this end river discharge is most often calculated with a hydrological model that includes a routing model, using either meteorological variables directly from GCMs (Aerts et al., 2006) or using observed meteorological time series perturbed with change factors derived from GCM results (Alcamo and Henrichs, 2002; Nijssen et al., 2001; Vörösmarty et al., 2000).

For a climate effect study it is possible to select datasets from multiple GCMs for multiple emission scenarios. Arnell (2003) showed that by 2050 there is little difference between the emission scenarios, i.e. correspondence between GCMs is weaker than between scenarios. This indicates that the choice of GCMs highly influences the calculated change and it has been concluded before that a multi-model ensemble of GCMs provides the most reliable impression of the spread and uncertainties of possible changes (Boorman and Sefton, 1997; IPCC, 2007; Murphy et al., 2004). Arnell (2003), Milly et al. (2005), Nohara et al. (2006) and Nijssen et al. (2001) used these multi-model ensembles.

All studies in Table A (see Supplement) indicated directions and amount of change for world regions or river basins, however quantification of the significance of these changes frequently played a minor role. In this study we will make a thorough assessment of the global hydrological effects of climate change by directly applying daily climate data from an ensemble of twelve GCMs for the IPCC SRES scenario A1B for the period 2081-2100 as input to the global hydrological model PCR-GLOBWB. In this hydrological model river discharge is calculated using an explicit routing scheme based on the kinematic wave equation, which also includes temporal storage in flood plains, lakes, wetlands and reservoirs. The relative changes between the current and future climate are analyzed instead of absolute changes, hereby reducing the influence of biases in the hydrological model and GCM data.

In addition, to investigating annual mean changes in runoff fields and changes in river regimes as has also been done in previous studies, we will here focus on: (1) spatial patterns of change in the annual cycle looking at changes in timing of peak, (2) additional discharge statistics (e.g. maximum and minimum flow and interannual discharge variability), (3) likelihood of change which is calculated here for each model individually relative to its inter-annual variability, and finally focus will be on (4) the consistency amongst model projections on the direction of change. This enables us to indicate on world maps in which regions the likelihood of hydrological changes is large.

\section{Methods}

The distributed global hydrological model PCR-GLOBWB (Van Beek et al., 2011; Van Beek and Bierkens, 2009; Bierkens and van Beek, 2009) was run on a daily timestep with meteorological time series from 12 GCMs for the 20C3M experiment for the period 1971-1990 and the SRES scenarios A1B for the period 2081-2100. From the results we derived change fields of discharge regimes for which the consistency amongst GCMs was quantified. We selected 19 large catchments (Fig. 1) which cover a variety of climate zones, latitudes and continents. For these catchments changes in the mean annual cycle are quantified. The setup of the study is schematized in Fig. 2.

\subsection{Hydrological model}

PCR-GLOBWB is a global distributed hydrological model with a resolution of $0.5^{\circ}$. The model shows similar performance as other global hydrological models and in addition to most existing global hydrological models it contains a kinematic wave routing routine which enables the calculation of 


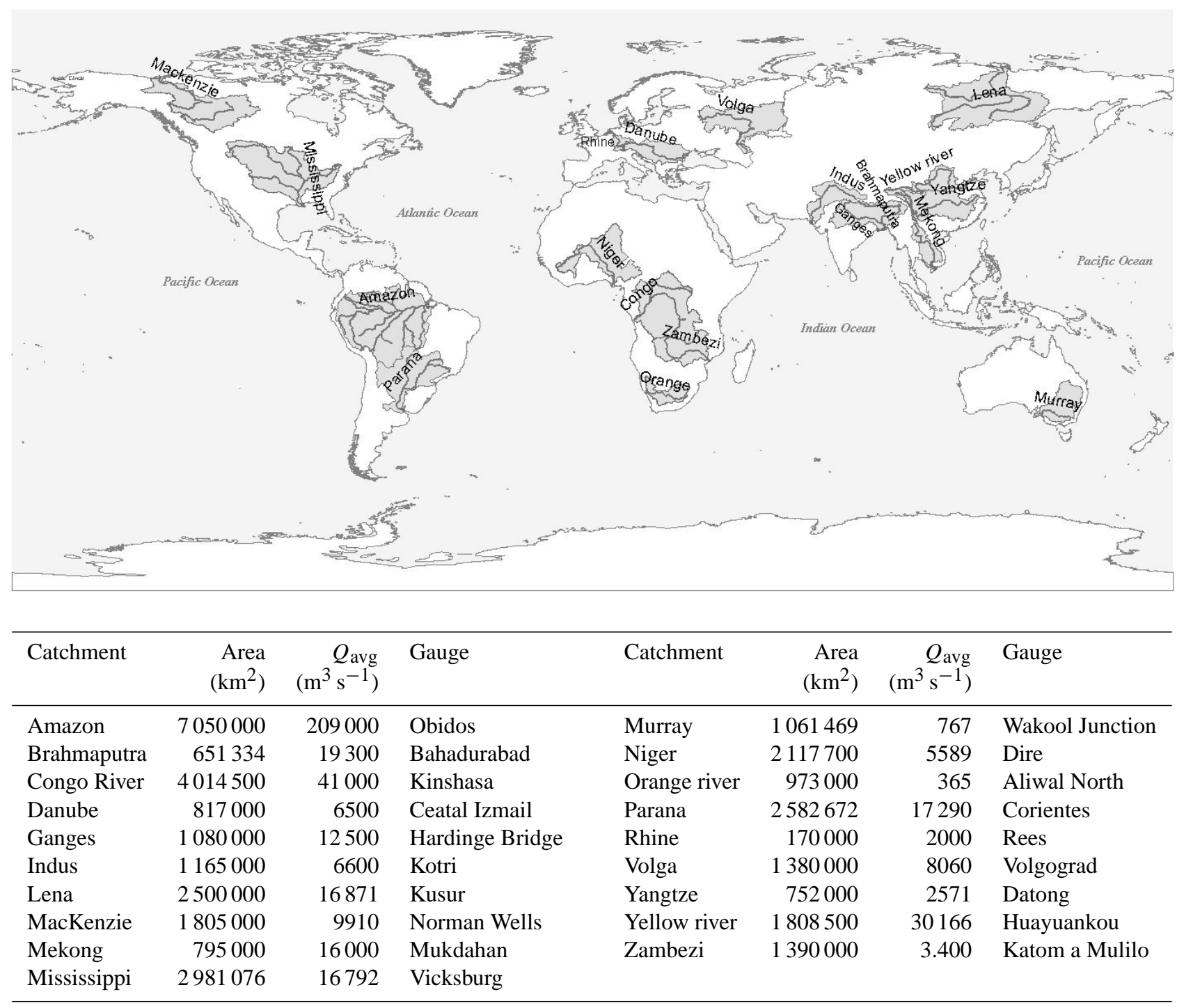

Fig. 1. Selected catchments with total catchment area, average observed discharge ( $Q_{\text {avg }}$; GRDC, 2007) and location of gauges for which statistics are calculated, annual cycles are given and comparisons are made.

a realistic annual river discharge cycle (Sperna Weiland et al., 2011). Here only a short description of the model is provided, for an extended description and evaluation of the model see Van Beek et al. (2011).

Each PCR-GLOBWB model cell consists of two vertical soil layers and one underlying groundwater reservoir. Subgrid parameterization is used to represent fractions of short and tall vegetation, surface water and for calculation of saturated areas to quantify surface runoff and lateral outflow from the unsaturated zone. Water enters the cell as rainfall and can be stored as canopy interception or snow. Snow accumulation or melt depends on temperature (degree day method) and melt water and throughfall are passed to the surface. Evapotranspiration is calculated from the potential evaporation and soil moisture conditions. Vertical exchange of water is possible between the soil and groundwater layers. Runoff is made up of non-infiltrating melt and throughfall water, saturation excess surface runoff, interflow and base flow. For each time-step the water balance is computed per cell. Runoff is accumulated and routed as river discharge along the drainage network taken from DDM30 (Döll and Lehner, 2002) using the kinematic wave approximation of the Saint-Venant equation. Adaptations have been made to the network to improve the inclusion of storage in lakes, wetlands and large reservoirs. Hereto a selection of substantial lakes and reservoirs $\left(\geq 500 \mathrm{~km}^{2}\right)$ was obtained from the GLWD1 data set (Lehner and Döll, 2004). The resulting river discharge represents natural flow. Water and reservoir management, river regulation and other human influences have not been included. Model parameterization is based on best 


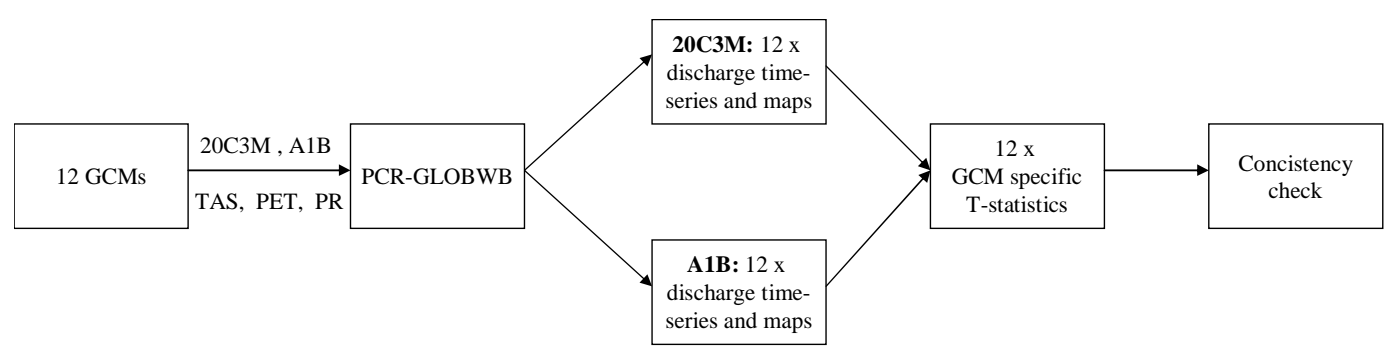

Fig. 2. Schematization of experimental setup.

available global datasets and so far the model has not been calibrated. More information about the model performance can be found in Van Beek et al. (2011).

Because of some apparent deviations, mostly caused by biases in meteorological forcing and additionally by simplifications in model structure and related scale issues, we will focus on relative changes between current and future discharges instead of absolute values. To overcome initialization problems, initial states have been obtained for each GCM dataset individually. For the control climate experiment and the future scenario, PCR-GLOBWB was initialized in a two step approach. In the first step the hydrological model was spin-up with a $30 \mathrm{yr}$ run, based on a combined dataset created from the CRU TS 2.1 (New et al., 2000) and the ERA-40 re-analysis (Uppala et al., 2005) datasets. The end-states of this run are used as initial states for the second step of the initialization. In this second step, the hydrological model is run for a $10 \mathrm{yr}$ period with data from the specific GCM. The end-states of these ten year runs are used as initial states for the hydrological model runs for the individual GCMs analyzed in this study. In summary this means that each GCM based run has its own initial conditions which are derived from data of that specific GCM.

\subsection{Climate data}

Required model inputs are precipitation, temperature and reference potential evaporation. Temperature and rainfall data can directly be obtained from the GCMs. Reference potential evaporation is derived using a modification of the PenmanMonteith equation where missing air humidity fields are not required (Allen et al., 1998; Monteith, 1965). For those models where other required variables (e.g. radiation, air pressure, windspeed, minimum air temperature) were missing the simpler temperature based Blaney-Criddle equation was used (Brouwer and Heibloem, 1986; Oudin et al., 2005). We realize this may have introduced additional noise between the model results (Kay and Davies, 2008). Therefore, in Supplement B, an analysis of the influence of using either BlaneyCriddle or Penman-Monteith to calculate potential evaporation, on the modeled discharges and discharge changes is given. Within the hydrological model, crop specific potential evaporation is calculated based on global monthly crop factor maps. These crop factor maps are derived from current land use (Van Beek, 2008). For the future runs possible changes in land use and growing season are neglected.

The Program for Climate Model Diagnosis and Intercomparison (PCMDI) collected model results from GCM runs based on the IPCC SRES scenarios and made the results available through the PCMDI data portal (https://esg. llnl.gov:8443/index.jsp). We selected the emission scenario $\mathrm{A} 1 \mathrm{~B}$, which is positioned at the upper range of possible $\mathrm{CO}_{2}$ emissions. This rather extreme scenario was selected since for the period 2000 to 2006 observed $\mathrm{CO}_{2}$ emissions have been larger than estimated by models (Canadell et al., 2007; Global Carbon project, 2008). In addition the signal to noise ratio is relatively clear for an extreme scenario, especially for a time horizon of 2100. Complete datasets, with the required variables available on a daily time-step for both the $20 \mathrm{C} 3 \mathrm{M}$ control experiment (1971-1990) and the A1B emission scenario (2081-2100), could be retrieved for twelve GCMs (see Table 1). Unfortunately the data availability restricted this analysis to these twelve GCMs, although a larger GCM ensemble would provide more information on uncertainty. Furthermore a longer period would have been better for averaging out inter-decadal variability. However, for the future experiments data were only available for a $30 \mathrm{yr}$ period for some of the GCMs. Although the data portal does not provide all required variables for the Hadley centre climate models, HadGEM1 has been included for it is frequently used in climate change studies. HadGEM1 data has been retrieved from the CERA-gateway (http://cera-www.dkrz.de).

For a few GCMs multiple realizations were provided (five GCMs with two or more realizations). To avoid unequal influence of the different GCMs on the ensemble mean change and because the consistency amongst changes projected by multiple realization from a single GCM tends to be larger than the consistency of changes projected by an ensemble of multiple GCMs, we only included one run per GCM in our ensemble. In Supplement $\mathrm{C}$ a brief analysis of the consistency of the multiple realizations for the GCM with the highest number of realizations for both the 20C3M experiment and the A1B scenario (CGCM2.3.2) is given. 
Table 1. Overview of selected GCMs.

\begin{tabular}{|c|c|c|c|c|c|}
\hline Model & Institute & Country & $\begin{array}{l}\text { Horizontal } \\
\text { resolution } \\
\text { (degrees) }^{*}\end{array}$ & $\begin{array}{l}\text { Vertical } \\
\text { resolution } * *\end{array}$ & Acronym \\
\hline BCM2.0 & Bjerknes Centre for Climate Research & Norway & 2.8 & $(31,35)$ & BCCR \\
\hline CGCM3.1 & Canadian Centre for Climate Modelling and Analysis & Canada & 3.75 & $(31,29)$ & CCCMA \\
\hline CGCM2.3.2 & Meteorological Research Institute & Japan & 2.8 & $(30,23)$ & CGCM \\
\hline CSIRO-Mk3.0 & Commonwealth Scientific and Industrial Research Organization & Australia & 1.875 & $(18,31)$ & CSIRO \\
\hline ECHAM5 & Max Planck Institute & Germany & 1.5 & $(31,40)$ & ECHAM \\
\hline ECHO-G & Freie Universität Berlin & Germany & 3.75 & $(19,20)$ & $\mathrm{ECHO}$ \\
\hline GFDL-CM 2.1 & Geophysical Fluid Dynamics Centre & USA & 1.0 & $(24,50)$ & GFDL \\
\hline GISS-ER & Goddard institute for Space Studies & USA & $4 \times 5$ & $(20,13)$ & GISS \\
\hline IPSL-CM4 & Institute Pierre Simon Laplace & France & $2.5 \times 3.75$ & $(19,19)$ & IPSL \\
\hline MIROC3.2 & Center of Climate System Research & Japan & 2.8 & $(20,43)$ & MIROC \\
\hline CCSM3 & National Center for Atmospheric Research & USA & 1.4 & $(26,40)$ & NCAR \\
\hline HadGEM1 & Met Office's Hadley Centre for Climate Prediction & UK & $1.25 \times 1.875$ & $(38,40)$ & HADGEM \\
\hline
\end{tabular}

* Parkinson et al. (2006); ${ }^{* *} \mathrm{nr}$ atmospheric layers, $\mathrm{nr}$ ocean layers

\subsection{Statistical analysis}

\subsubsection{Statistics}

To quantify the projected hydrological changes between the future and control experiments and the consistency of these changes, consistency maps were derived. In the following sections we describe how changes in these statistical quantities are obtained from the multi-model ensemble and how the likelihood and consistency of the changes have been quantified.

\subsubsection{Relative change}

Discharge changes have been calculated relative to the baseline multi-model simulations. We did not look at absolute values, because the GCM precipitation and consequently the derived discharges deviate from observed quantities for some of the catchments (Van Beek et al., 2011). The relative changes for the two scenarios have been calculated for each model individually, according to the following equation:

$\Delta Q_{\text {future }}=\left(\bar{Q}_{\text {future }}-\bar{Q}_{\text {past }}\right) / \bar{Q}_{\text {past }}$

where $\bar{Q}$ can be one of the statistics in Table 2, "past" refers to the 20C3M experiment and "future" refers to the A1B scenario. For the timing of peak discharges absolute changes were calculated. From the relative change fields per model $\left(\Delta Q_{i}\right)$ we calculated maps with the ensemble mean change $(\overline{\Delta Q})$ for the different statistics:

$\overline{\Delta Q}=\frac{1}{12} \sum_{i=i}^{12} \Delta Q_{i}$.

We prefer to work with a non weighted multi-model mean, since weights have to be derived from past performance and may not hold for future periods because of apparent small persistence in relative model skill (Reifen and Toumi, 2009). The multi model ensemble, with equal weights assigned to each member, is likely to give good results and contains all the uncertainty information available. Furthermore, weighting on a limited number of indices of GCM performance may result in a misleading estimate of change, because the more complex picture of the relative merits of the individual GCMs is hidden (Gosling et al., 2011).

\subsubsection{Likelihood and consistency}

Notable discharge changes, between the 20th century climate control experiment and the A1B scenario for 2100, were derived for each GCM individually relative to its inter-annual variability. This was done by applying the independent samples t-test. However, an inter-annual autocorrelation is expected to exist in the yearly runoff time series, resulting in an effective decrease of the number of independent observations. This dependency was accounted for by calculating the effective sample size from the lagged correlation coefficient, $\rho$, according to Matalas and Langbein (1962):

$\frac{1}{n_{b}^{*}}=\frac{1}{n}+\frac{2}{n^{2}} \sum_{j=1}^{n-1}(n-j) \rho_{j \Delta t}$

where $\Delta t$ is the observation interval (=1 yr), $n$ is the total number of observations and $j \Delta t$ is the time lag for which the correlation coefficient is calculated. With this equation values of $n_{b}^{*}$ (the effective sample size) were calculated for each model cell. Afterwards, independent two sample t-tests were conducted for each GCM individually using the effective sample size.

$t=\frac{\bar{Q}_{\text {fut }}-\bar{Q}_{\text {past }}}{S_{\text {fut_past }} \sqrt{\frac{1}{n_{\text {fut }}^{*}}+\frac{1}{n_{\text {past }}^{*}}}}$ 
Table 2. Parameters included in analysis. $Q_{\operatorname{mean}_{j}}, Q_{\min _{j}}$ and $Q_{\max _{j}}$ are respectively the mean, minimum and maximum daily discharge of year $j . j$ is the year number and ranges from 1 to $20 . N=20$, the total number of years. $Q_{\text {peak }_{j}}$ is the number of the month in which discharge peak occurred in year $j . \bar{Q}$ is the twenty year mean discharge. $\bar{P}_{\text {sum }}$ is the twenty year average annual basin total precipitation sum and $\overline{\mathrm{EACT}}_{\text {sum }}$ is the twenty year average annual basin total modeled actual evaporation sum.

\begin{tabular}{|c|c|c|}
\hline Parameter & Definition & Equation \\
\hline $\bar{Q}_{\min }$ & 20 yr average annual minimum discharge & $\bar{Q} \min =\frac{1}{N} \sum_{j=1}^{20} Q_{\min _{j}}$ \\
\hline $\bar{Q}_{\max }$ & 20 yr average annual maximum discharge & $\bar{Q} \max =\frac{1}{N} \sum_{j=1}^{20} Q_{\max _{j}}$ \\
\hline $\bar{Q}_{\text {mean }}$ & 20 yr average annual mean discharge & $\bar{Q}$ mean $=\frac{1}{N} \sum_{j=1}^{20} Q_{\text {mean }_{j}}$ \\
\hline $\bar{Q}_{\text {peak }}$ & $20 \mathrm{yr}$ mode of month in which yearly discharge peak occurs & $\bar{Q}_{\text {peak }}=\bmod \left(Q_{\text {peak }_{j}}\right)_{0, . ., j}$ \\
\hline Var & Inter-annual variability in mean annual discharge & $\operatorname{var}=\sqrt{\frac{1}{N}} \sum_{j=1}^{20}\left(Q_{\text {mean }_{j}}-\bar{Q}\right)^{2}$ \\
\hline $\mathrm{RC}$ & 20 yr average basin specific runoff coefficient & $\mathrm{RC}=\frac{\bar{P}_{\text {basin Total }}-\overline{\mathrm{EACT}}_{\text {basin Total }}}{\bar{P}_{\text {basin Total }}}$ \\
\hline
\end{tabular}

$S_{\text {fut_past }}=\sqrt{\frac{\left(n_{\text {fut }}^{*}-1\right) S_{\text {fut }}^{2}+\left(n_{\text {past }}^{*}-1\right) S_{\text {past }}^{2}}{\left(n_{\text {fut }}^{*}+n_{\text {past }}^{*}-2\right)}}$

where $S_{\text {fut }}$ and $S_{\text {past }}$ are respectively the standard deviation of yearly average minimum, maximum or mean discharge for the A1B scenario and the $20 \mathrm{C} 3 \mathrm{M}$ experiment. $\bar{Q}_{\text {fut }}$ and $\bar{Q}_{\text {past }}$ are the $20 \mathrm{yr}$ average discharge statistics for the A1B scenario and control experiment and $n_{\text {fut }}^{*}$ and $n_{\text {past }}^{*}$ are the effective degrees of freedom as calculated with Eq. (6).

We assume the distribution of mean, maximum and minimum discharge to be approximately Gaussian, a criterium that needs to be met for applying the above t-statistics. This criterium can not be met for the timing of peak discharge and inter-annual variability, therefore t-statistics are not calculated for these variables. In addition, discharges calculated from data of a single GCM for the different time-slices can not be assumed to be completely random samples as the meteorological data are generated with the same GCM (von Storch, 1995). Still we apply the above t-statistics, although only to distinguish notable changes from noise.

To quantify the consistency in projected change between the twelve models, the number of models projecting notable change in the dominant direction (i.e. the direction of the mean of the multi-model ensemble) was calculated for each individual model cell. The resulting consistency maps indicate for which regions of the world the models project consistent changes in discharge and where consequently likelihood of discharge changes is higher than in other regions.

\subsubsection{Annual cycle}

To illustrate the changes in monthly flows and possible seasonal shifts, mean annual cycles have been derived for each catchment. In the first step, mean annual cycles were derived over the twenty year model run period for each model individually for both the $20 \mathrm{C} 3 \mathrm{M}$ experiment and the A1B scenario. The two resulting sets of twelve GCM derived annual cycles gave for each month long-term average distributions of GCM derived discharge from which for the 20C3M experiment and A1B scenario individually the mean, 10th- and 90th-percentile discharges per month were calculated. By doing so the plots of the resulting annual regimes do not only give information on the changes in mean annual cycle, but also on the spread in the annual cycles obtained from the ensemble of models.

\section{Results}

Global maps with monthly mean discharge and actual and potential evaporation derived from the daily results of the GCM based hydrological model runs (e.g. hydrological scenario data) can be downloaded from: http://opendap.deltares. nl/thredds/dodsC/opendap/deltares/FEWS-IPCC.

\subsection{Global patterns of change}

In Fig. 3 global maps with the multi model ensemble average relative change in mean, minimum and maximum annual discharge are shown. Here mean discharge is the $20-\mathrm{yr}$ 


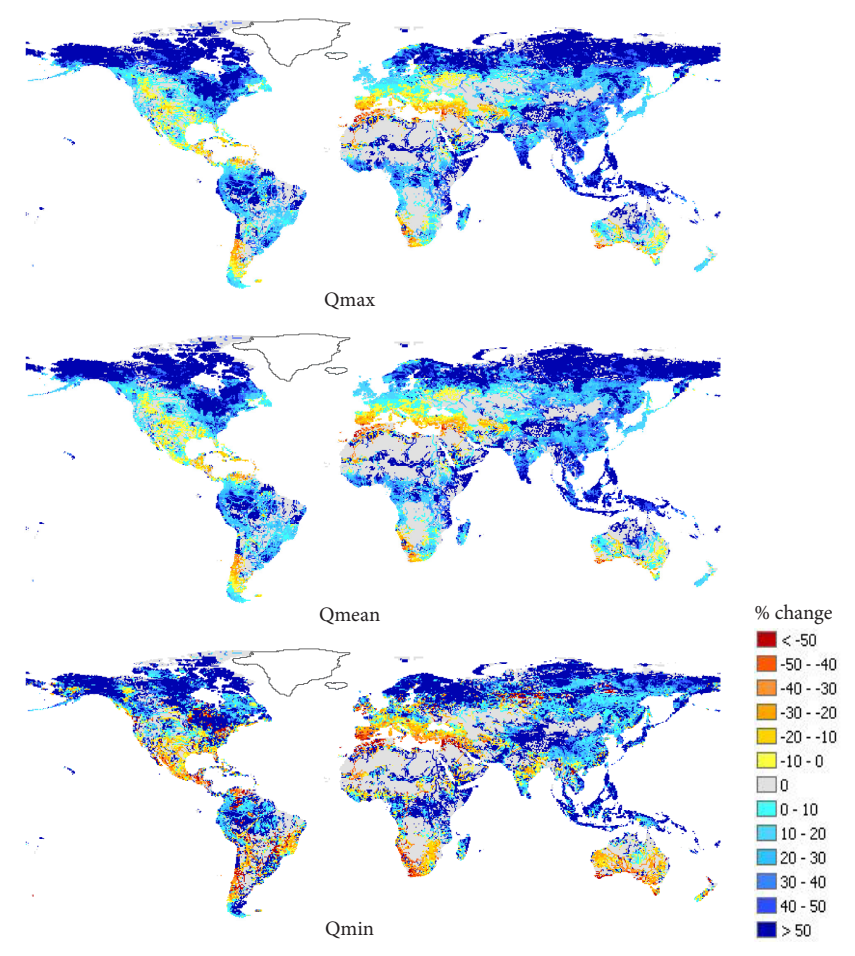

Fig. 3. Maps showing the multi-model ensemble average percentage change $(\%)$ in the hydrological parameters annual maximum, minimum and mean discharge for the emission scenario A1B relative to the $20 \mathrm{C} 3 \mathrm{M}$ control experiment.

average annual mean daily discharge, minimum discharge is the average of the minimum daily discharge calculated for the twenty individual years and maximum is the average of the maximum daily discharge calculated for the twenty individual years. The regions where minimum, maximum and mean discharge increase and decrease are the same, although regions with decreases are more extended for minimum discharge in the US and Eastern Europe and increases in maximum discharge are larger in Arctic and Sub-Arctic regions. Similar global patterns of change can be found in literature (Alcamo et al., 2007; Milly et al., 2005; Nohara et al., 2006). Several studies (Alcamo and Henrichs, 2002; Arnell, 1999; Vörösmarty et al., 2000) indicated large parts of the regions, for which we calculated discharge decreases, as areas currently experiencing water stress. According to these studies, water stress will increase for most of these areas, depending on the definition of the water use scenario.

Figure 4 shows ensemble average seasonal discharge changes. Seasonal changes in precipitation, temperature and actual evaporation were derived as well to explain discharge changes. However, for briefness, maps resulting from these calculations have not been included. Maximum discharge increases are projected for the Arctic and sub-Artic regions and for south-east Asia. These increases are related to an increase of precipitation in the JJA and SON seasons. Figure 4 shows that in North-Western Europe and the Eastern

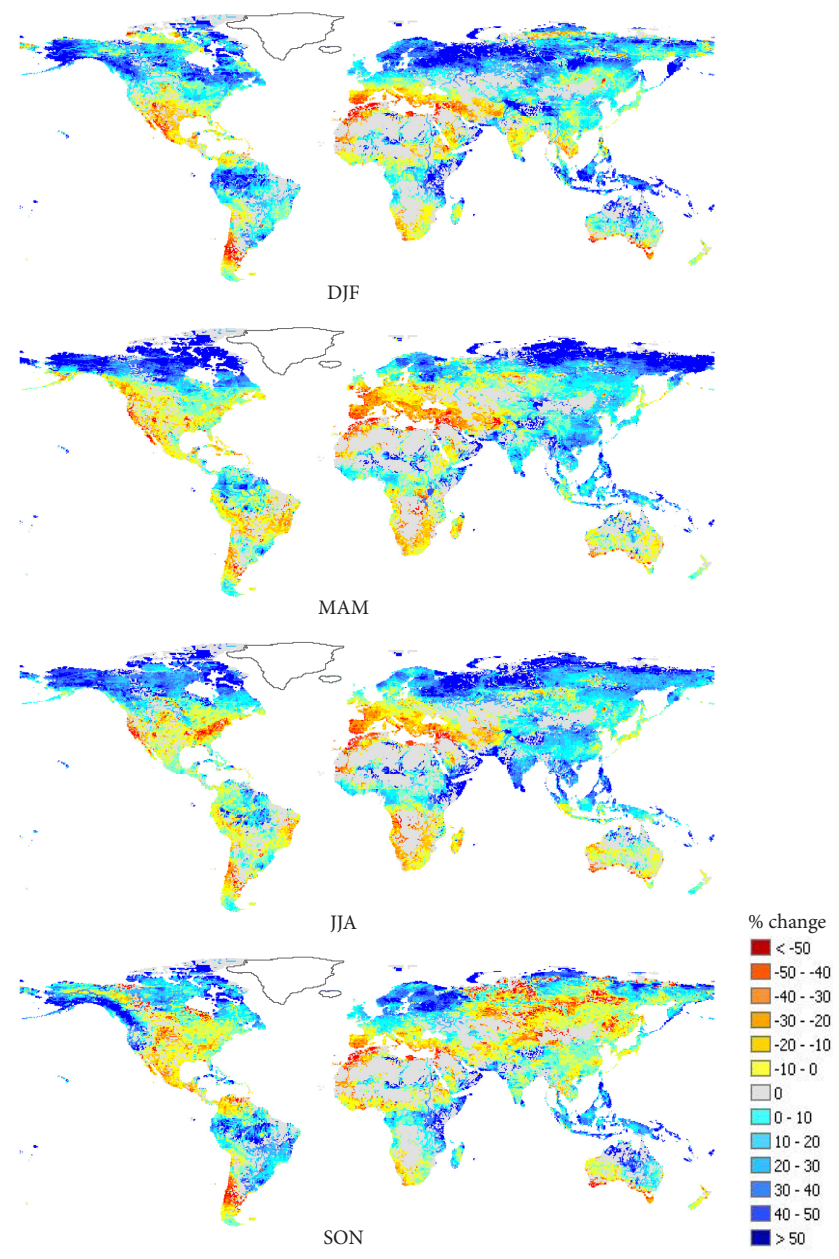

Fig. 4. Multi-model ensemble average seasonal discharge changes (\%) for the scenario A1B as a percentage of the discharges calculated for the $20 \mathrm{C} 3 \mathrm{M}$ control experiment. From top to bottom the seasons: December-January-February, March-April-May, JuneJuly-August and September-October-November.

US winter runoff increases while summer runoff will decrease. This mirrors changes in precipitation distribution over the year, with wetter boreal winters and drier boreal summers. Areas around the Mediterranean Sea, the southwest of South-America, parts of south and north Africa and the south of Australia experience discharge decreases caused by large precipitation decreases. In South Africa this precipitation decrease is accompanied by an evaporation increase for the DJF and MAM season. The seasonal patterns of precipitation and evaporation of the multi model mean show that during the summer (JJA) the African monsoon reaches further north which results in rainfall and discharge increases in the Northern Sahel.

In Fig. 5 the globe is divided in arid and humid regions based on the climate moisture indices of the WWDRII (UN, 2006). We indicated whether arid (humid) regions are expected to become wetter (drier) according to our global 


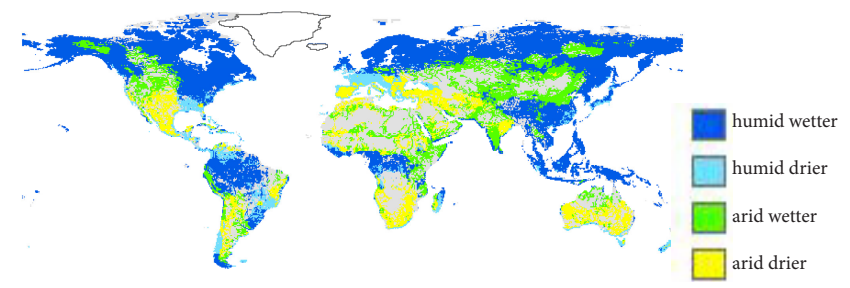

Fig. 5. Change in aridity. The division in humid and arid regions is obtained from the WWRDII climate moisture indices (UN, 2006). The globe is divided in humid regions becoming wetter (dark blue), humid regions becoming drier (light blue), arid regions becoming wetter (green) and arid regions becoming drier (yellow) based on the ensemble average change calculated for the A1B scenario.

ensemble mean projected changes (Fig. 3). For the arid regions; Southern Africa, the northern African coast, southern Australia, the southern US and Spain discharge decreases are projected. The more humid part of southern Europe will experience discharge decreases, for most other humid world regions (e.g. southeast Asia, Arctic and sub-Arctic regions, eastern US, the Amazon) discharge increases are projected. Current dry regions for which discharge increases are projected are northern Australia, parts of Asia, Russia and the centre of the US. For northern Africa discharge increases are projected as well, however in absolute values these increases are negligible.

Besides change in runoff quantities, maps with shift in timing of peak discharge were calculated by taking the difference between the ensemble mode of the month of peak occurrence for the A1B scenario and the 20C3M experiment (Fig. 6). For large parts of the world, shifts are less than a month. There is a shift backward in time for most of the sub-Arctic regions. This shift is caused by increased temperatures for the spring and summer season resulting in earlier snowmelt and more precipitation falling as rain. For parts of South-Asia a shift forward in peak timing of a half up to one month is calculated. This may result from a delay in the Monsoon rainfall that shifts from the JJA to the SON season, caused by a later reversal of the meridional tropospheric temperature gradient (Ashfaq et al., 2009). However the plots of the annual cycles of other Monsoon influenced rivers do not show this shift. For most southern parts of the world changes are mixed. And, although shifts in timing are also displayed for deserts and tropic regions, they contain limited information since precipitation is relatively constant throughout the year in these regions and consequently the annual cycle has only a small amplitude.

\subsection{Consistency on global patterns of change}

GCM consistency maps for change in the different hydrological variables are given in Figs. 7 and 8. In these figures, likelihood of change is quantified for the individual GCMs relative to the GCM specific $20 \mathrm{yr}$ inter-annual variability.

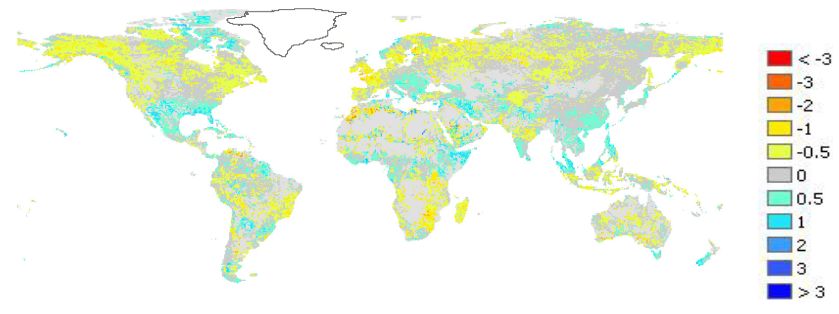

Fig. 6. Map showing the number of months change in the timing of peak discharge occurrence calculated by taking the mode of the ensemble of timings calculated for the twelve individual GCMs for the scenario A1B relative to to $20 \mathrm{C} 3 \mathrm{M}$ control experiment.

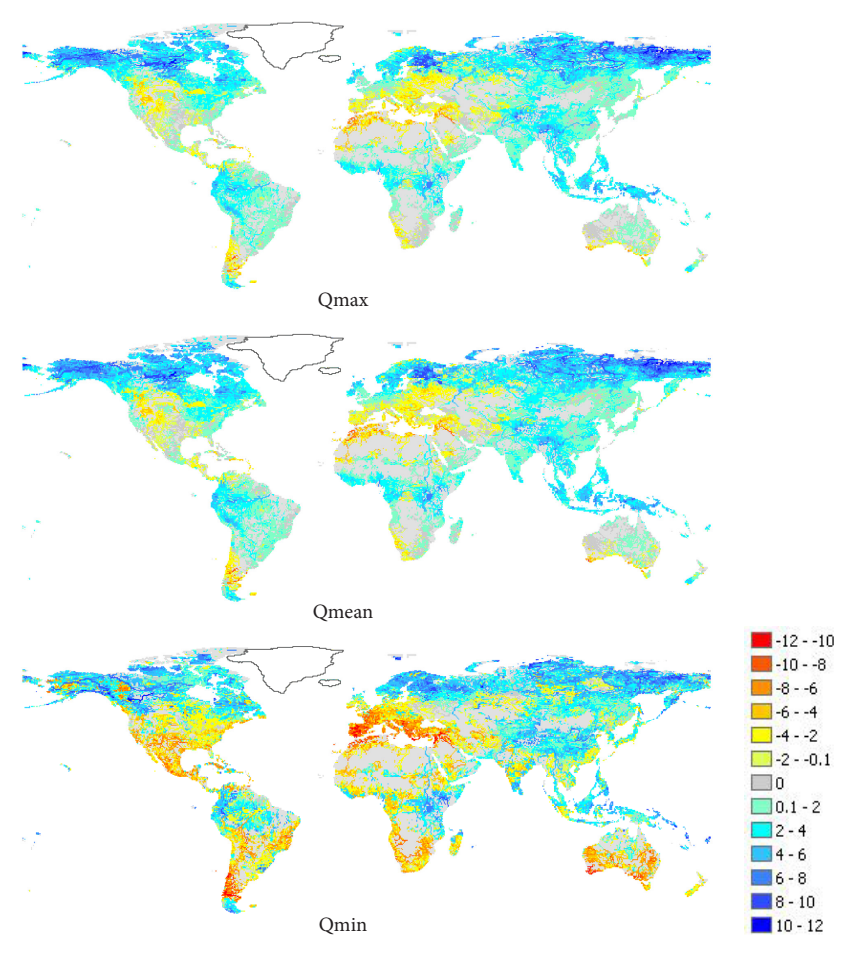

Fig. 7. Maps showing the number of models projecting significant change (for a significance level of $5 \%$ ) in the same direction as the ensemble mean direction of change (see Sect. 2.4 for more information). From top to bottom the figure shows GCM consistencies for maximum, mean and minimum discharge. Negative values correspond to the number of models projecting discharge decrease, positive values correspond to the number of models projecting discharge increases, grey areas correspond to areas with no significant change.

By using this analysis it is possible to denote regions with notable change, despite the uncertainty between models and possible model dependencies. Consistent significant change amongst GCMs is especially large for increases in annual mean discharge in the Arctic regions and minimum discharge decreases in southern Australia, southern Europe, parts of Africa and the south-western coast of South-America. There is less agreement between the models on the changes in 


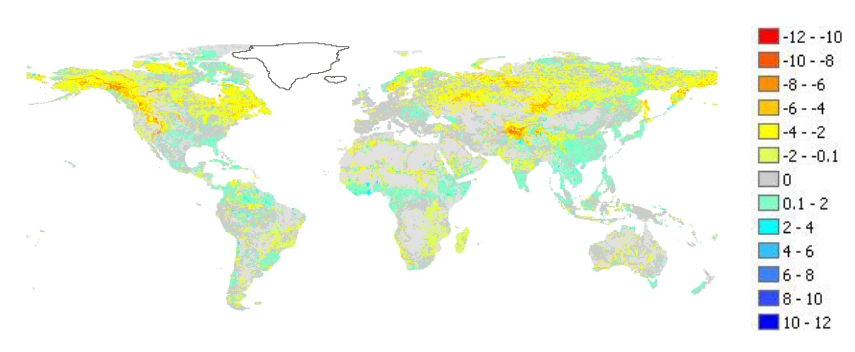

Fig. 8. Maps showing the number of models projecting change in timing of the annual cycle consistent with the ensemble mean direction of change of timing. The negative numbers correspond to the number of models projecting advances in the annual cycle consistent with the ensemble mean advances, positive numbers correspond to consistent projected delays in the timing of regime, grey areas correspond to regions with zero change.

minimum and especially maximum discharge than on change in mean discharge. Consensus on seasonal shift of peak discharge (Fig. 8) is large for sub-Arctic regions where temperature rise causes an earlier snow melt driven discharge peak. For dry areas the timing of peak is difficult to assess due to low discharge values and small amplitudes, therefore models show little consensus on the direction of change in these regions.

\subsection{Continental discharge changes}

For each continent and each ocean the change in freshwater flowing into the oceans was calculated by summing the $20 \mathrm{yr}$ average mean accumulated runoff of rivers discharging into the oceans (Fig. 9). For all continents discharge to oceans increases according to the ensemble mean change. This confirms that there will be an intensification of the hydrological cycle (Huntington, 2006).

Discharge increases are smallest for Africa, Europe and South-America, as multiple GCMs also project discharge decreases for large parts of these continents. In Australia and Africa, despite the continental discharge increases, the effects of discharge decreases are large since they mainly occur in regions that are already arid at this stage (see in Fig. 5 the projected decreases in the arid regions of southern Africa and southern Australia including the Murray basin). Inflow to the oceans will increase for all oceans except the Mediterranean Sea. Inflow to the Mediterranean Sea originates from Southern Europe and Northern Africa, both regions with projected discharge decreases. Large discharge decreases for the Mediterranean region, up to $40 \%$, have also been found by Sanchez-Gomez et al. (2009).

The spread in projected changes is smallest for Europe and South-America. Here discharge increases and decreases projected by the individual GCMs are small and the resulting ensemble mean projected change is close to zero. For the other continents ensemble mean change as well as the ensemble uncertainty is larger. For Australia and Asia a consistent discharge increase is projected and, although for Africa and North-America increases are projected as well, the ensemble mean change is smaller as some GCMs project discharge decreases.

Globally we find an ensemble mean discharge increase of $11.0 \%$ by 2100 . In contrast, Arnell (1999) found a slight decrease for the HadCM2 ensemble; by 2080 an ensemble mean decrease of mean discharge from $-0.4 \%$. Although three of the four individual ensemble members of his ensemble gave a discharge increase ranging between 0.6 and $1.0 \%$. For the HadCM3 model he found a decrease of $-14.7 \%$. This illustrates the large differences amongst models. Vörösmarty et al. (2000) found a global discharge decrease of $-5.6 \%$ for their time horizon of 2025 and Arora and Boer (2001) found a larger decrease of $-14 \%$ by the end of the 21 st century. These differences might be a result of the use of the previous version of IPCC scenarios. However, more likely they are a result of the uncertainty between GCMs. Even for global average changes in temperature there is less variance amongst selected emission scenarios than amongst projections obtained from different GCMs. Depending on the selected scenario, the ensemble range of projected temperature ranges from 1.5 to $3^{\circ} \mathrm{K}$ (Kelvin) or 2 to $4.5^{\circ} \mathrm{K}$. While the absolute projected global temperature changes is on average $2^{\circ} \mathrm{K}$ temperature increase for the $1 \% \mathrm{CO}_{2}$ increase scenario Arnell (1999) used, $3 \mathrm{~K}$ increase for the IS92a scenario Arora and Boer (2001) followed and $3 \mathrm{~K}$ increase for the A1B scenario used in this study (IPCC, 2007). GCM ensemble uncertainty ranges for projected precipitation ranges are even larger (see Table 3).

\subsection{Catchment results}

Mean annual discharge cycles of the selected river basins are shown in Fig. 10 for the control experiment 20C3M, the A1B scenario and for discharge observations. Furthermore percentage changes in $20 \mathrm{yr}$ average minimum, maximum, mean discharge and runoff coefficient, absolute changes in timing of peak discharge, and changes in variability are shown in Table 4. Variations between the individual GCMs are large and changes in discharge projected by individual GCMs are even contradictory for certain catchments.

The projections show large discharge increases for the Yangtze, Mekong, Yellow river, Indus and Brahmaputra. Furthermore, maximum discharge increases for these rivers, as well as for the Ganges are likely. These changes are caused by an increase in Monsoon rainfall related to an increase of sea surface temperature increasing the moisture holding capacity of air above sea (Meehl and Arblaster, 2003). From the ensemble of GCMs an increase in precipitation is calculated for the JJA and SON seasons in this region. In general the different studies agree upon this increase in river discharge for the Asian Monsoon influenced rivers. Yet, small differences exist with the study of Arora and Boer (2001) for the Mekong and Yangtze and the study 

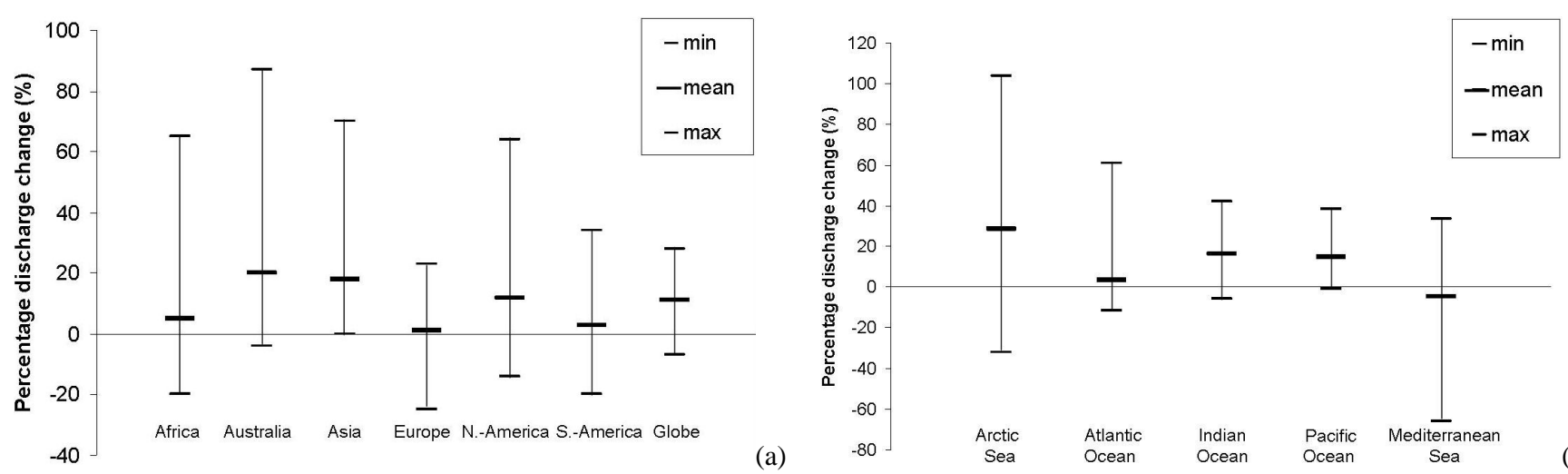

Fig. 9. (a) Continental discharge changes (\%), (b) change in freshwater inflow to oceans (\%). Vertical bars represent range of changes covered by the entire ensembles of GCMs, large horizontal dashes represent ensemble mean change, small horizontal dashes represent minimum and maximum projected changes.

Table 3. Change in global temperature (K), precipitation $(\%)$ and discharge (\%) for different emissions scenarios.

\begin{tabular}{|c|c|c|c|c|c|}
\hline Temperature & $\begin{array}{r}\text { Ensemble } \\
\text { min }\end{array}$ & $\begin{array}{r}\text { Ensemble } \\
\text { mean }\end{array}$ & $\begin{array}{r}\text { Ensemble } \\
\max \end{array}$ & Horizon & Source \\
\hline $1 \% \mathrm{CO}_{2}$ & 1.5 & 2 & 3 & 2100 & Andrews and Forster (2010) \\
\hline IS92a & 2 & 3 & 4.5 & 2100 & IPCC (2007) \\
\hline A1B & 2 & 3 & 4.5 & 2100 & IPCC (2007) \\
\hline \multicolumn{6}{|c|}{ Precipitation } \\
\hline $1 \% \mathrm{CO}_{2}$ & 2 & 4 & 6 & 2100 & Andrews and Forster (2010) \\
\hline IS92a & 1.5 & 4 & 6 & 2100 & IPCC (2007) \\
\hline A1B & 1.5 & 4.5 & 7 & 2100 & IPCC (2007) \\
\hline \multicolumn{6}{|c|}{ Discharge } \\
\hline $1 \% \mathrm{CO}_{2}$ & -14.7 & -0.4 & 1 & 2080 & Arnell (1999) \\
\hline IS92a & & -14 & & 2100 & Arora and Boer (2001) \\
\hline A1B & -7 & 11 & 28 & 2100 & This study \\
\hline
\end{tabular}

of Nijssen et al. (2001) for the Yellow river. This is a result of difference in GCMs used and differences in selected emission scenarios, which is probably of minor relevance given the large uncertainty between GCMs.

A decrease in mean discharge is projected for the African rivers; Zambezi, Orange and Niger. Furthermore the Zambezi shows a decrease of the 10-percentile of ensemble discharge towards no flow. Especially for the south of Africa, estimated precipitation decreases are large. The discharge decreases are in agreement with results of Arora and Boer (2001) who calculated a decrease of mean annual discharge for the warmer world and Nohara et al. (2006), who found decreases for the African rivers. For the Orange river the large decrease in discharge results in a related ensemble mean decrease of inter-annual discharge variability.

For the Lena and Mackenzie a large discharge increase was estimated, which is related to earlier snowmelt due to higher temperatures and a calculated increase in precipitation for the SON season that is stored during winter as snow.
Nijssen et al. (2001) and Nohara et al. (2006) calculated an advance in peak for Arctic rivers, which can also be seen form our annual cycle plots. Arora and Boer (2001) also found an advance in phase for the high-latitude rivers and an increase in amplitude.

Discharge decreases are calculated for the Murray, the 10th percentile discharge even decreases to zero. Precipitation decreases and summer (JJA) evaporation increases are large for Australia. Our results for the Murray do not compare well with the results of Aerts et al. (2006). A pronounced difference was found here. They calculated a $43 \%$ increase while we obtained a $14 \%$. The difference might be caused by the difference in reference period used, which was 1750 to 2000 in their study. Within a longer reference period the inter-annual variability is likely to be larger and periods with relatively low discharge may have occurred before. Derived changes can therefore be smaller than the changes we derived from our 20-yr reference period. 

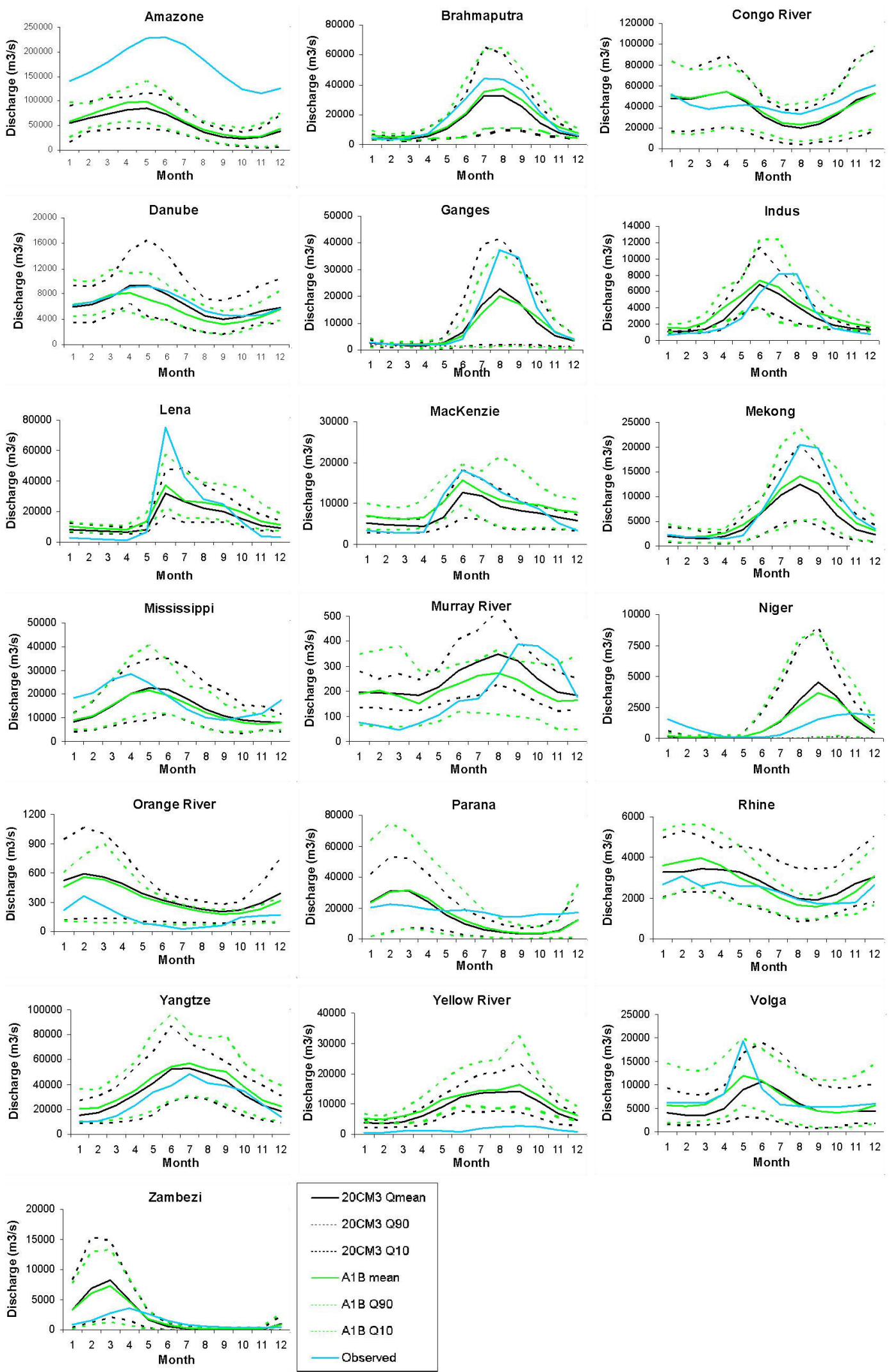

Fig. 10. Modeled annual hydrological cycles for the 19 selected catchments, showing for each experiment the monthly 20-yr average discharge and the monthly 10th and 90th percentile discharge derived from the discharges calculated from the 12 GCM datasets. 
Table 4. Percentage change for the hydrological parameters of interest (see Table 3). Calculated for the A1B experiment, relative to the $20 \mathrm{C} 3 \mathrm{M}$ experiment.

\begin{tabular}{lrrrrrr}
\hline & $\begin{array}{r}\mathrm{A} 1 \mathrm{~B} \\
\Delta Q_{\text {mean }} \\
(\%)\end{array}$ & $\begin{array}{r}\mathrm{A} 1 \mathrm{~B} \\
Q_{\max } \\
(\%)\end{array}$ & $\begin{array}{r}\mathrm{A} 1 \mathrm{~B} \\
Q_{\text {min }} \\
(\%)\end{array}$ & $\begin{array}{r}\Delta Q_{\text {peak }} \\
(\text { month })\end{array}$ & $\begin{array}{r}\mathrm{A} 1 \mathrm{~B} \\
\Delta \text { var } \\
(\%)\end{array}$ & $\begin{array}{r}\mathrm{A} 1 \mathrm{~B} \\
(-)\end{array}$ \\
\hline Amazon & 13 & 22 & -6 & 0.2 & 5 & 16 \\
Bramaputra & 14 & 35 & 10 & -0.6 & 8 & 1 \\
Congo river & 3.0 & 9 & 1 & -0.3 & 2 & 7 \\
Danube & -11 & -16 & -29 & 0.4 & -2 & -6 \\
Ganges & -2 & 12 & -28 & 0.4 & 3 & -6 \\
Indus & 25 & 29 & 23 & -0.1 & 19 & -5 \\
Lena & 21 & 47 & 11 & -0.1 & 17 & -5 \\
Mackenzie & 28 & 36 & 25 & -0.5 & 7 & 0 \\
Mekong & 21 & 52 & 9 & 0.6 & 3 & 13 \\
Mississippi & -5 & 5 & -17 & 0.2 & 3 & -10 \\
Murray river & -14 & 0 & -23 & -0.1 & 0 & 24 \\
Niger & -53 & 19 & $*$ & -0.3 & 4 & -10 \\
Orange river & -10 & 5 & -24 & 1.3 & -5 & 5 \\
Parana & 4 & 9 & -28 & 0.3 & -3 & 19 \\
Rhine & -2 & 4 & -31 & -0.5 & 8 & -1 \\
Volga & 21 & 19 & 23 & -0.1 & 14 & -4 \\
Yangtze & 14 & 23 & 19 & 0.2 & 4 & 0 \\
Yellow river & 19 & 33 & 22 & -0.1 & 10 & -1 \\
Zambezi & -3 & -6 & $*$ & -0.7 & -2 & 14 \\
\hline
\end{tabular}

* The minimum flow in the Zambezi and Niger becomes zero for several GCMs for the future climate therefore $\%$ changes are omitted here.

Large discharge decreases are likely for the Danube. Precipitation decreases are large in both the Danube and the Rhine basin in particular for the summer period. Discharge of the Rhine overall decreases but there is an increase in maximum discharge. This is related to the calculated temperature increases, leading to earlier snowmelt and an increased amount of spring precipitation falling as rain instead of snow which enters the river earlier in the year. The study of Nohara et al. (2006) showed a decrease in discharge for the river Danube and Rhine as well. However, again there is a difference with Aerts et al. (2006) who found little change in Danube discharge.

\subsection{Change in catchment specific runoff coefficients}

To quantify the relative change in water balance partitioning due to climate change, the change in runoff coefficients (RC; for the definition see Table 2) has been calculated for all individual catchments for the selected measurement stations (see percentage changes in the last column Table 4). For the calculations, twenty year average year sums of accumulated upstream precipitation and actual evaporation have been used to avoid the influence of storage changes in glaciers and soil water. Basins with an increase of RC of more than $10 \%$ are the Amazon, Parana, Murray, Zambezi, Mississippi and Mekong. For the Mekong this increase is caused by an increase in precipitation. The Parana also experiences an increase in precipitation together with a decrease of actual evaporation. For the Murray and Zambezi the decrease in actual evaporation is larger than the decrease in precipitation, also resulting in increasing RC. Except for the Niger, the African rivers all have an increasing runoff coefficient, indicating that the part of precipitation that evaporates decreases. The Niger is the only basin with a decrease in RC of more than $10 \%$. This decrease is caused by small changes in precipitation and large evaporation increases. The runoff coefficient decreases for the Danube and Rhine (slight decrease), due to a decreasing amount of precipitation and because a larger part of the precipitation will evaporate due to temperature increases.

\section{Discussion}

In an attempt to make an as complete as possible assessment of the global hydrological effects of climate change we provided and overview of previous hydrological studies and presented our results in the context of the previous results. We used a, for global scale hydrological studies, relatively large ensemble of GCMs existing of all the GCMs for which the PCMDI data portal provided the required daily time-series of meteorological variables which were needed as input to the hydrological model. We estimated changes in spatial and temporal discharge variability and calculated the ensemble consistency of the projected changes. In addition to previous studies we quantified likelihood of change relative to the individual GCM inter-annual variability. By using this alternative analyses of calculating likelihood of change relative to the GCMs inter-annual variability, it is possible to denote regions with notable change, despite the uncertainty between models.

Although using an ensemble of GCMs for the estimation of future change is often recommended (Boorman and Sefton, 1997; Murphy et al., 2004) previous studies also criticized the use of the ensemble mean change (Materia et al., 2010). By averaging the results of multiple GCMs extremes are reduced, discharge cycles are smoothened and changes become less pronounced. Still, by using multiple models, all available information is considered in the analysis, the influence of discrepancies in single models is reduced and model uncertainties can be analyzed. In addition, by investigating the ensemble consistency, regions with large uncertainties and discrepancies between models are identified.

Here, one should realize that the uncertainties obtained from the ensemble of GCMs are merely model structural uncertainties, resulting from our still limited understanding of atmospheric processes. They do not represent real world uncertainties. Yet, as real world uncertainties are unknown, the ensemble uncertainties at least provide us with some quantification of the probability of change required for amongst other proper adaptation strategies (Beven, 2011). Although the biases present in GCM data hamper reliable hydrological climate change impact assessments, they still provide the 
best available means for assessing future changes (Pielke et al., 2009; Beven, 2011).

From an evaluation of the $12 \mathrm{GCMs}$ on the reproduction of the annual discharge cycles and hydrological extremes for the catchments included in this analysis, we concluded that for each basin other GCMs perform best and a sub-set which outperforms the other GCMs for all basins and hydrological variables included in this analysis does not exist. Therefore the full ensemble was used.

Furthermore, it should be noted that the hydrological model introduces uncertainties as well, amongst others due to structural simplifications and parameter uncertainties and the absence of anthropogenic influences as for example water use and river regulation in the routing scheme (Sperna Weiland et al., 2010; Van Beek et al., 2011; Vrugt et al., 2003). For a full uncertainty assessment, multiple hydrological models should be employed here. Unfortunately, such a study quickly becomes unfeasible. Here, we restricted ourselves to a multiple GCM analysis as Gosling et al. (2011) already stated in their multi- hydrological and climate model comparison for multiple basins around the world, that the range in projections from different hydrological models is smaller than the range of projections from different GCMs.

This study is restricted to hydrological changes due to climate change, for a full assessment of future water availability the impact of climate change on hydrological change should be placed in light of other factors as for example population growth, land use change and water management. The impact of these factors may be comparable or larger than the impact of climate change (Beven, 2011; Pielke et al., 2009; Vörösmarty et al., 2000; Alcamo et al., 2007; Arnell, 2004).

The result of this study show that river discharge will increase for the Yangtze, Yellow river, Mekong, Ganges, Indus and Brahmaputra due to an increase in monsoon rainfall. As a result of earlier snowmelt and an increase of precipitation the Lena and MacKenzie show an increase in spring discharge and a small shift in timing of peak. A decrease in both mean and extreme discharge is projected for the Orange, Niger, Murray and Danube. Comparable results have been found in previous studies especially when looking at global patterns of change, but differences exist both on catchment and continental scale.

Changes in the downstream part of the river basins and especially in the main river courses are often more likeliy than the changes for grid cells located upstream in the catchment. This may be because variations in climate patterns are accumulated downstream. It confirms the importance of discharge accumulation and the use of a routing scheme that, although biases are present for several catchments, allows for temporal storages in lakes and reservoirs and introduces realistic travel times which are especially relevant in larger catchments like the Amazon (Sperna Weiland et al., 2011).

The climate models do not always project consistent changes, especially for areas with temperate climate. In addition to the information on the discharge change maps, the consistency maps (Fig. 7) indicate the agreement amongst models on the direction of significant change in relation to inter-annual variability and thereby give an indication of regions where discharge is likely to be affected by climate change. Such an analysis partly accounts for the influence of GCM model errors and may be the preferred change detection method for grid-based global assessment of discharge change.

According to the ensemble mean calculations, continental outflow to oceans will increase for all oceans except for the Mediterranean Sea. The GCMs project a consistent decrease in runoff for southern Europe, South Australia, South Africa, parts of north Africa and the southwestern coast of SouthAmerica. There is also large consensus on discharge increase for the Arctic regions and the Northern Sahel. Besides these results, the following three findings are useful to hydrological climate effect studies in general. First, we found that the projected changes in our study show the largest differences with studies based on a small number of climate models. When using only small ensembles the response may be biased through the influence of only one or two GCMs that deviate from the other models, while in larger ensemble these deviating GCMs will have less influence due to the averaging of multiple change projections. This underscores the value of using large ensembles. Second, from the differences with the study of Aerts et al. (2006) it can be concluded that choice of the reference period influences the change signal. Aerts et al. (2006) used data for the period 1750 to 2000 as a reference for the change projections and to investigate the influence of interdecadal variability. When using a reference period of this length the influence of inter-annual variability is minimized, whereas in our twenty year period it is more likely that the average discharge is disturbed by effects like El Nino. Furthermore, in this study change is calculated between 2100 and the time-slice 1961-1990, which is likely to represent current climate conditions. Whereas Aerts et al. (2006) calculated change relative to the period 1750-2000 and changes will therefore either be relatively large or less extreme due to long-term variations in the climate that resemble future climate changes. Third and finally, our results are comparable to studies using the change factor method which, for computational reasons, might therefore be the preferable method to use.

\section{Conclusions}

In this paper we successfully revealed the regions of the world where notable and consistent hydrological changes are projected. By 2100 hydrological model runs, based on an ensemble of GCMs, project a consistent decrease in runoff for southern Europe, southern Australia, the south and north of Africa and southwestern South-America. Significant discharge decreases are also projected for most African rivers, for the Murray and for the Danube. Runoff increases are 
projected for sub-Arctic and Arctic regions and an advance in phase in the annual cycle is projected for the sub-Arctic regions. Overall, discharge of Monsoon influenced rivers slightly increases.

The results of this study are generally comparable to previous studies. Although, results of studies using only a small number of GCMs show relatively large differences from our study and the use of a multi-model ensemble is therefore preferable. We illustrated that by considering the consistency of change amongst models (i.e. in light of the likelhood of projected change relative to natural variability) regions with high likelihood of changes in the annual cycle can clearly be revealed.

\section{Supplementary material related to this article is available online at: http://www.hydrol-earth-syst-sci.net/16/1047/2012/ hess-16-1047-2012-supplement.pdf.}

Acknowledgements. We acknowledge the GCM modeling groups, the Program for Climate Model Diagnosis and Intercomparison (PCMDI) and the WCRP's Working Group on Coupled Modelling (WGCM) for their roles in making available the WCRP CMIP3 multi-model dataset. Support of this dataset is provided by the Office of Science, US Department of Energy. We would like to thank the reviewers, R. T. Clarke, B. Fekete, S. Materia and G. A. Corzo, for their extensive review comments which greatly helped us to improve the quality of this manuscript.

Edited by: J. Liu

\section{References}

Aerts, J., Renssen, H., Ward, P. J., de Moel, H., Odada, E., Bouwer, L. M., and Goosse, H.: Sensitivity of global river discharges under Holocene and future climate conditions, Geophys. Res. Lett., 33, L19401, doi:10.1029/2006GL027493, 2006.

Alcamo, J. and Henrichs, T.: Critical regions: A model-based estimation of world water resources sensitive to global changes, Aquat. Sci., 64, 1-11, 2002.

Alcamo, J., Flörke, M., and Märker, M.: Future long-term changes in global water resources driven by socio-economic and climatic changes, Hydrolog. Sci. J., 52, 247-275, 2007.

Allen, R. G., Pereira, L. S., Raes, D., and Smith, M.: Crop evapotranspiration: FAO Irrigation and drainage paper 56, FAO, Rome, Italy, 1998.

Andrews, T. and Forster, P. M.: The transient response of globalmean precipitation to increasing carbon dioxide levels, Environ. Res. Lett., 5, 025212, doi:10.1088/1748-9326/5/2/025212, 2010.

Arnell, N. W.: Climate change and global water resources, Global Environ. Change, 9, 831-849, 1999.

Arnell, N. W.: Effects of IPCC SRES* emissions scenarios on river runoff: a global perspective, Hydrol. Earth Syst. Sci., 7, 619641, doi:10.5194/hess-7-619-2003, 2003.

Arnell, N. W.: Climate change and global water resources: SRES emissions and socio-economic scenarios, Global Environ. Change, 14, 31-52, doi:10.1016/j.gloenvcha.2003.10.006, 2004.
Arora, V. K. and Boer, G. J.: Effects of simulated climate change on the hydrology of major river basins, J. Geophys. Res., 106, 3335-3348, 2001.

Ashfaq, M., Shi, Y., Tung, W., Trapp, R. J., Gao, X., Pal, J. S., and Diffenbaugh, N. S.: Suppression of south Asian summer monsoon precipitation in the 21 st century, Geophys. Res. Lett., 36, L01704, doi:10.1029/2008GL036500, 2009.

Beven, K.: I believe in climate change cut how precautionary do we need to be in planning for the future, Hydrol. Process., 25, 1517-1520, doi:10.1002/hyp.7939, 2011.

Bierkens, M. F. P. and Van Beek, L. P. H.: Seasonal predictability of european discharge: NAO and hydrological response time, J. Hydrometeorol., 10, 953-968, 10.1175/2009JHM1034.1, 2009.

Boorman, D. B. and Sefton, C. E. M.: Recognizing the uncertainty in the quantification of the effects of climate change on hydrological response, Climatic Change, 35, 415-434, 1997.

Brouwer, C. and Heibloem, M.: Irrigation water management: Irrigation water needs, FAO, Rome, Italy, 1986.

Canadell, J. G., Le Quéré, C., Raupach, M. R., Field, C. B., Buitehuis, E. T., Ciais, P., Conway, T. J., Houghton, R. A., and Marland, G.: Contributions to accelerating atmospheric $\mathrm{CO}_{2}$ growth from economic activity, carbon intensity, and efficiency of natural sinks, P. Natl. Acad. Sci., 104, 18866-18870, 2007.

Covey, C., AchutaRao, K. M., Cubasch, U., Jones, P., Lambert, S. J., Mann, M. E., Phillips, T. J., and Taylor, K. E.: An overview of results from the coupled model intercomparison project, Global Planet. Change, 37, 103-133, doi:10.1016/S0921-8181(02)00193-5, 2003.

Döll, P. and Lehner, B.: Validating of a new global 30-minute drainage direction map, J. Hydrol., 258, 214-231, 2002.

Fowler, H. J., Blenkinsop, S., and Tebaldi, C.: Review: Linking climate change modelling to impact studies: recent advances in downscaling techniques for hydrological modeling, Int. J. Climatol., 27, 1547-1578, doi:10.1002/joc.1556, 2007.

Giorgi, F. and Mearns, L. O.: Calculation of average, uncertainty range, and reliability of regional climate changes from AOGCM simulations via the "Reliability Ensemble Averageing" (REA) method, J. Climate, 15, 1141-1158, 2002.

Global Carbon Project Carbon budget and trends 2007: http://www. globalcarbonproject.org, last access: 26 September 2008.

Gosling, S. N., Taylor, R. G., Arnell, N. W., and Todd, M. C.: A comparative analysis of projected impacts of climate change on river runoff from global and catchment-scale hydrological models, Hydrol. Earth Syst. Sci., 15, 279-294, doi:10.5194/hess-15279-2011, 2011.

GRDC: Major River Basins of the World/Global Runoff Data Centre, D - 56002, Federal Institute of Hydrology (BfG), Koblenz, Germany, 2007.

Huntington, T. G.: Evidence for intensification of the global water cycle: Review and synthesis, J. Hydrol., 319, 83-95, 2006.

Immerzeel, W. W., Van Beek, L. P. H., and Bierkens, M. F. P.: Climate change will affect the Asian water towers, Science, 328, 1382-1385, doi:10.1126/science.1183188, 2010.

IPCC: Climate Change 2007: The Physical Science Basis Contribution of Working Group I to the Fourth Assessment Report of the Intergovernmental Panel on Climate Change, Cambridge University Press, Cambridge, UK and New York, NY, USA, 996 pp., 2007. 
Kay, A. L. and Davies, V. A.: Calculating potential evaporation from climate model data: A source of uncertainty for hydrological climate change impacts, J. Hydrol., 358, 221-239, 2008.

Kingston, D. G., Todd, M. C., Taylor, R. G., and Thompson, J. R.: Uncertainty in the estimation of potential evapotranspiration under climate change, Geophys. Res. Lett., 36, L20403, doi:10.1029/2009GL040267, 2009.

Lehner, B. and Döll, P.: Development and validation of a global dataset of lakes, reservoirs and wetlands, J. Hydrol., 296, 1-22, 2004.

Liu, J., Fritz, S., Van Wesenbeeck, C. F. A., Fuchs, M., You, L., Obersteiner, M., and Yang, H.: A spatially explicit assessment of current and future hotspots of hunger in Sub-Saharan Africa in the context of global change, Global Planet. Change, 64, 222235,2008 .

Liu, J., Zehnder, A. J. B., and Yang, H.: Global consumptive water use for crop production: The importance of green water and virtual water, Water Resour. Res., 45, W05428, doi:10.1029/2007WR006051, 2009.

Matalas, N. C. and Langbein, W. B.: Information content of the mean, J. Geophys. Res., 67, 3441-3448, 1962.

Materia, S., Dirmeyer, P. A., Guo, Z., Alessandri, A., and Navarra, A.: The sensitivity of simulated river discharge to land surface representation and meteorological forcings, J. Hydrometeorol., 11, 334-351, 2010.

Meehl, G. A. and Arblaster, J. M.: Mechanisms for projected future changes in south Asian monsoon precipitation, Clim. Dynam., 21, 659-675, doi:10.1007/s00382-003-0343-3, 2003.

Meehl, G. A., Zwiers, F., Evans, J., Knutson, T., Mearns, L., and Whetton, P.: Trends in extreme weather and climate events: issues related to modelling extremes in projections of future climate change, B. Am. Meteorol. Soc., 81, 427-436, 2000.

Milly, P. C. D., Dunne, K. A., and Vecchia, A. V.: Global pattern of trends in streamflow and water availability in a changing climate, Nature, 438, 347-350, doi:10.1038/nature04312, 2005.

Monteith, J. L.: Evaporation and environment, Symp. Soc. Exp. Biol., 19, 205-234, 1965.

Murphy, J. M., Sexton, D. M. H., Barnett, D. N., Jones, G. S., Webb, M. J., Collins, M., and Stainforth, D. A.: Quantification of modelling uncertainties in a large ensemble of climate change simulations, Nature, 430, 768-772, 2004.

New, M., Hulme, M., and Jones, P.: Representing TwentiethCentury space-time climate variability, Part 1: Development of a 1961-90 mean monthly terrestrial climatology, J. Climate, 12, 829-856, 2000.

Nijssen, B., O’Donnel, G. M., Hamlet, A. F., and Lettenmaier, D. P.: Hydrologic sensitivity of global rivers to climate change, Climatic Change, 50, 143-175, 2001.

Nohara, D., Kitoh, A., Hosaka, M., and Oki, T.: Impact of climate change on river discharge projected by multimodel ensemble, J. Hydrometeorol., 7, 1076-1089, 2006.

Oki, T. and Kanae, S.: Global hydrological cycles and world water resources, Science, 313, 1068-1072, 2006.

Oudin, L., Hervieu, F., Michel, C., Perrin, C., Andréassian, V., Anctil, F., and Loumagne, C.: Which potential evapotranspiration input for a lumped rainfall-runoff model? Part 2 - Towards a simple and efficient potential evapotranspiration model for rainfallrunoff modeling, J. Hydrol., 303, 290-306, 2005.
Parkinson, C. L., Vinnikov, K. Y., and Cavalieri, D. J.: Evaluation of the simulation of the annual cycle of Arctic and Antarctic sea ice coverages by 11 major global climate models, Geophys. Res. Lett., 111, C07012, doi:10.1029/2005JC003408, 2006.

Pielke, R., Beven, K. J., Brasseur, G., Calvert, J., Chahine, M., Dickerson, R., Entekhabi, D., Foufoula-Georgiou, E., Gupta, H., Gupta, V., Krajewski, W., Krider, E. P., Lau, W. K. M., McDonnell, J. J., Rossow, W., Schaake, J., Smith, J., Soroosh, S., and Wood, E. F.: Climate change: the need to consider human forcings other than greenhouse gases, EOS, Transactions-American Geophysical Union, 90, 413 pp., 2009.

Reifen, C. and Toumi, R.: Climate projections: past performance no guarantee of future skill, Geophys. Res. Lett., 36, L13704, doi:10.1029/2009GL038082, 2009.

Sanchez-Gomez, E., Somot, S., and Mariotti, A.: Future change in the Mediterranean water budget projected by an ensemble of regional climate models, Geophys. Res. Lett., 36, L21401, doi:0.1029/2009GL040120, 2009.

Sperna Weiland, F. C., van Beek, L. P. H., Kwadijk, J. C. J., and Bierkens, M. F. P.: The ability of a GCM-forced hydrological model to reproduce global discharge variability, Hydrol. Earth Syst. Sci., 14, 1595-1621, doi:10.5194/hess-14-15952010, 2010.

Sperna Weiland, F. C., Van Beek, L. P. H., Kwadijk, J. C. J., and Bierkens, M. F. P.: On the suitability of GCM runoff fields for river discharge modeling; a case study using model output from HadGEM2 and ECHAM5, J. Hydrometeorol., 13, 140-154, doi:10.1175/JHM-D-10-05011.1, 2011.

UN: 2nd UN World Water Development Report: WWDRII data download page, http://wwdrii.sr.unh.edu/download.html (last access: November 201), 2006.

Uppala, S. M., Kållberg, P. W., Simmons, A. J., Andrae, U., da Costa Bechtold, V., Fiorino, M., Gibson, J. K., Haseler, J., Hernandez, A., Kelly, G. A., Li, X., Onogi, K., Saarinen, S., Sokka, N., Allan, R. P., Andersson, E., Arpe, K., Balmaseda, M. A., Beljaars, A. C. M., van de Berg, L., Bidlot, J., Bormann, N., Caires, S., Chevallier, F., Dethof, A., Dragosavac, M., Fisher, M., Fuentes, M., Hagemann, S., Hólm, E., Hoskins, B. J., Isaksen, L., Janssen, P. A. E. M., Jenne, R. A., McNally, P., Mahfouf, J.-F., Morcrette, J.-J., Rayner, N. A. R., Saunders, W., Simon, P., Sterl, A., Trenberth, K. E., Untch, A., Vasiljevic, D., Viterbo, P., and Woollen, J.: The ERA-40 re-analysis, Q. J. Roy. Meteorol. Soc., 131, 2961-3012, 2005.

Van Beek, L. P. H.: Forcing PCR-GLOBWB with CRU meteorological data, http://vanbeek.geo.uu.nl/suppinfo/vanbeek2008. pdf, last access: November 2011, Utrecht University, Utrecht, The Netherlands, 2008.

Van Beek, L. P. H. and Bierkens, M. F. P.: The Global Hydrological Model PCR-GLOBWB: Conceptualization, Parameterization and Verification, Report Department of Physical Geography: available at: http://vanbeek.geo.uu.nl/suppinfo/ vanbeekbierkens2009.pdf, last access: November 2011, Utrecht University, Utrecht, The Netherlands, 2009.

Van Beek, L. P. H., Wada, Y., and Bierkens, M. F. P.: Global monthly water stress: I. Water balance and water availability, Water. Resour. Res., 47, W07517, doi:10.1029/2010WR009791, 2011. 
Viviroli, D., Archer, D. R., Buytaert, W., Fowler, H. J., Greenwood, G. B., Hamlet, A. F., Huang, Y., Koboltschnig, G., Litaor, M. I., López-Moreno, J. I., Lorentz, S., Schädler, B., Schreier, H., Schwaiger, K., Vuille, M., and Woods, R.: Climate change and mountain water resources: overview and recommendations for research, management and policy, Hydrol. Earth Syst. Sci., 15, 471-504, doi:10.5194/hess-15-471-2011, 2011.

Vörösmarty, C. J., Green, P., Salisbury, J., and Lammers, R. B.: Global water resources: Vulnerability from climate change and population growth, Science, 289, 284-288, 2000.
Von Storch, H.: Misuses of statistical analysis in climate research, in: Analysis of Climate Variability: Applications of Statistical Techniques, edited by: von Storch, H. And Navarra, A., Springer-Verlag, Berlin, 11-26, 1995.

Vrugt, J. A., Gupta, H. V., Bouten, W., and Sorooshian, S.: A shuffled complex evolution Metropolis algorithm for optimization and uncertainty assessment of hydrological model parameters, Water Resour. Res., 39, 1201, doi:10.1029/2002WR001642, 2003. 